\title{
HUBUNGAN STATUS PEKERJAAN IBU DENGAN STATUS GIZI BALITA
}

\section{The Correlation Between Occupational Status of Mother and Nutritional Status Of Toddler}

\author{
Nenes Riana Fauzia ${ }^{1}$, N.M.A Sukmandari ${ }^{2}$, K. Yogi Triana ${ }^{2}$ \\ ${ }^{1}$ Program Studi S1 Keperawatan, STIKES Bina Usada Bali, Badung, Bali, Indonesia \\ ${ }^{2}$ Departemen Keperawatan Anak, STIKES Bina Usada Bali Bina Usada Bali, Badung, Bali, Indonesia \\ Korespondensi: arisukmandarimd@gmail.com
}

\begin{abstract}
ABSTRAK
Status gizi balita sangat berhubungan dengan faktor ekonomi. Sementara itu kondisi ekonomi keluarga tergantung dari pekerjaan kedua orang tuanya. Ibu yang bekerja memiliki waktu yang lebih sedikit untuk mengurus anaknya sehingga akan berpengaruh pada kualitas perawatan balita sehingga mempengaruhi status gizi balita. Tujuan penelitian ini untuk mengetahui Hubungan Status Pekerjaan Ibu dengan Status Gizi Pada Anak Balita di Wilayah Kerja UPT Puskesmas Kuta Utara Tahun 2018. Penelitian ini menggunakan desain cross sectional dengan jumlah sampel 61 orang ibu bekerja yang dipilih melalui teknik purposive sampling dengan menggunakan kriteria inklusi dan ekslusi. Uji statistik yang digunakan yaitu Spearman Rank ( $\mathrm{p}$ value $<\mathrm{p}, \mathrm{p}=0,05$ ). Hasil uji univariat menunjukkan bahwa frekuensi ibu bekerja sebanyak 35 responden $(55,7 \%)$, frekuensi status gizi balita terbanyak adalah kategori normal sebanyak 44 responen $(72,1 \%)$. Hasil uji bivariat diperoleh $p$ value $=0,001<0,05$, maka dapat disimpulkan bahwa ada hubungan yang signifikan antara status pekerjaan ibu dengan status gizi balita di Wilayah Kerja Upt Puskesmas Kuta Utara. Berdasarkan hasil penelitian tersebut diharapkan perawat dapat mengedukasi para ibu untuk dapat membagi atau mengatur waktunya dalam pekerjaan sehingga dapat memperhatikan status gizi anak balitanya.
\end{abstract}

Kata Kunci: ibu bekerja, status gizi, balita

\section{ABSTRACT}

Nutritional status of toddlers is closely related to economic factors. Meanwhile the family's economic condition depends on the work of his parents. Working mothers have less time to care for their children so that it will affect the quality of care for children so that it affects the nutritional status of children. The purpose of this study was to determine the correlation of occupational status of mother with nutritional status of toddler. This study used a cross sectional design with a sample of 61 working mothers who were selected through a purposive sampling technique using inclusion and exclusion criteria. The statistical test used is Spearman Rank ( $\mathrm{p}$ value $<\mathrm{p}, \mathrm{p}=0.05)$. The results of the univariate test showed that the frequency of working mothers was 35 respondents $(55.7 \%)$, the frequency of the highest nutritional status of children under five was the normal category of 44 responses $(72.1 \%)$. Bivariate test results obtained $\mathrm{p}$ value $=0.001<0.05$, it can be concluded that there is a significant relationship between the employment status of mothers with nutritional status of children in the North Sumatra Health Center Upt Work Area. Based on the results of these studies it is expected that nurses can educate mothers to be able to divide or manage their time in work so they can pay attention to the nutritional status of their toddler.

Keywords: working mothers, nutritional status, toddler 


\section{PENDAHULUAN}

Masalah gizi di Indonesia yang terbanyak meliputi gizi kurang atau mencakup susunan hidangan yang tidak seimbang maupun konsumsi keseluruhan yang tidak mencukupi kebutuhan badan. Anak balita (1-5 tahun) merupakan kelompok umur yang paling sering menderita kekurangan gizi atau termasuk salah satu kelompok masyarakat yang rentan kekurangan gizi. Gizi kurang atau gizi buruk pada balita dapat berakibat terganggunya pertumbuhan jasmani dan kecerdasan mereka. Jika banyak balita yang masuk dalam status gizi kurang atau buruk maka balita tersebut akan sulit dalam berkembang. Dengan demikian masalah gizi merupakan masalah terpenting bagi masyarakat dan keluarga untuk memperbaiki status gizi pada balita (Adriani, 2012).

Usia balita merupakan usia dimana pertumbuhan dan perkembangan terjadi sangat pesat. Dihitung sejak hari pertama kehamilan, kelahiran bayi sampai usia 2 tahun atau yang dikenal dengan periode 1000 hari pertama kehidupan manusia merupakan "periode emas" atau "periode kritis" yang menentukan kualitas kehidupan (Wirjatmadi, 2012). Asupan gizi yang cukup baik dalam kuantitas dan kualitas sangat diperlukan pada masa ini. Apabila kebutuhan zat gizi ini tidak terpenuhi maka pertumbuhan dan perkembangan anak akan terhambat, yang akhirnya akan menyebabkan mereka akan menjadi generasi yang hilang (lost generation) (Wirjatmadi, 2012).

Prevalensi status gizi balita di Indonesia berdasarkan Riset Kesehatan Dasar (Riskesdas) tahun 2010 pada kategori gizi buruk sebanyak $6,7 \%$, gizi kurang sebanyak 6,9\%, gizi baik sebanyak $69,6 \%$, dan gizi lebih sebanyak 16,8\%. Saat ini Indonesia termasuk salah satu dari 117 negara yang mempunyai tiga masalah gizi tinggi pada balita yaitu stunting, wasting dan overweight yang dilaporkan di dalam Global Nutrition Report (GNR) tahun 2014. Prevalensi ketiga masalah gizi tersebut yaitu stunting $37,2 \%$, wasting $12,1 \%$ dan overweight 11,9\% (IFPRI, 2014).
Faktor-faktor yang mempengaruhi status gizi antara lain: kurangnya informasi, kurangnya daya beli masyarakat, dan pekerjaan orang tua. Pekerjaan orang tua berkaitan dengan pendapatan keluarga, sehingga bisa dikatakan bahwa jenis pekerjaan juga bisa menentukan seseorang untuk memenuhi kebutuhan gizi keluarga. Ibu yang bekerja memiliki waktu yang lebih sedikit untuk mengasuh anaknya dibandingkan ibu yang tidak bekerja, sehingga akan berpengaruh pada kualitas perawatan anak sehingga mempengaruhi status gizi anak. Ibu yang bekerja dengan jam kerja pagi sampai sore maka ibu tidak mempunyai banyak waktu untuk memperhatikan makanan dan kebutuhan nutrisi anaknya (Agus, 2012).

Bekerja umumnya merupakan kegiatan yang menyita waktu. Bekerja bagi ibu-ibu akan mempunyai pengaruh terhadap kehidupan sehingga ibu tidak punya banyak waktu untuk mendapat informasi. Manusia memerlukan pekerjaan untuk dapat berkembang dan berubah. Seseorang bekerja bertujuan untuk mencapai suatu keadaan yang lebih dari keadaan yang sebelumnya. Seseorang yang bekerja dapat berbuat sesuatu yang bernilai, bermanfaat, dan memperoleh berbagai pengalaman (Nafi'ah, 2015).

Berdasarkan latar belakang di atas, penulis ingin meneliti tentang "Hubungan status pekerjaan ibu dengan status gizi pada balita di Wilayah Kerja UPT Puskesmas Kuta Utara" Agar dapat memberikan manfaat untuk meningkatkan status gizi pada balita.

\section{TUJUAN PENELITIAN}

Tujuan penelitian ini adalah untuk menganalisa hubungan status pekerjaan ibu dengan status gizi pda balita di wilayah kerja UPT Puskesmas Kuta Utara.

\section{METODE PENELITIAN}

Desain

Penelitian ini menggunakan metode kuantitatif yaitu observasional yang menggunakan desain penelitian cross sectional. Instrumen pengumpulan data menggunakan lembar observasi. Untuk menganalisis hubungan status pekerjaan ibu 
Nenes Riana Fauzia: Hubungan Status Pekerjaan Ibu Dengan Status Gizi pada Balita di Wilayah Kerja UPT Puskesmas Kuta Utara Tahun 2018

dengan status gizi pada balita maka dilakukan uji statistik Spearman Rank dengan tingkat signifikansi $\mathrm{p}<0,05$ dan tingkat kepercayaan 95\%.

\section{Populasi dan Sampel}

Populasi dalam penelitian ini adalah seluruh balita yang dirawat dan dipantau perkembangannya di wilayah kerja UPT Puskesmas Kuta Utara. Jumlah sampel dalam penelitian ini sebanyak 61.Teknik pengambilan sampel menggunakan nonprobability sampling yaitu purposive sampling.

\section{Tempat dan Waktu Penelitian}

Penelitian ini bertempat di wilayah kerja UPT Puskesmas Kuta Utara, dengan waktu pengumpulan data dilaksanakan selama 5 minggu.

\section{Instrumen dan Prosedur Pengukuran}

Instrumen pengumpulan data menggunakan lembar observasi. Balita akan melakukan pengukuran antopometri dan penilaian status gizi.

\section{Analisa Data}

Pengukuran hubungan status pekerjaan ibu dengan status gizi pada balita maka dilakukan uji statistik Spearman Rank dengan tingkat signifikansi $\mathrm{p}<0,05$ dan tingkat kepercayaan 95\%.

\section{HASIL PENELITIAN}

Berikut ini akan disajikan hasil penelitian, yaitu:

Tabel 1

Karakteristik Responden ( $\mathrm{n}=61)$

\begin{tabular}{lcccccc}
\hline \multicolumn{1}{c}{ Variabel } & n & \% & Min & Max & Mean & SD \\
\hline Usia & & & 14 & 51 & 29,85 & 10 \\
\hline Jenis & & & & & & \\
Kelamin & & & & & & \\
Laki-Laki & 33 & 54 & & & & \\
Perempuan & 28 & 46 & & & & \\
\hline Pekerjaan & & & & & & \\
$P N S$ & 26 & 42 & & & & \\
IRT & 9 & 15 & & & & \\
Swasta & 8 & 13 & & & & \\
Wiraswasta & 18 & 30 & & & & \\
\hline
\end{tabular}

\begin{tabular}{lcc}
\hline $\begin{array}{l}\text { Status } \\
\text { Pekerjaan }\end{array}$ & & \\
Bekerja & & \\
Tidak & 35 & 57 \\
Bekerja & 26 & 43 \\
\hline Status Gizi & & \\
Kurus & 6 & 10 \\
Normal & 44 & 72 \\
Gemuk & 11 & 18 \\
\hline
\end{tabular}

Tabel 1 menunjukkan bahwa memiliki usia rata-rata 29,85 (30) bulan dengan usia tertinggi 51 bulan dan usia terendah 14 bulan dengan nilai standar deviasi 10. Jumlah responden yang paling banyak adalah berjenis kelamin laki-laki yaitu sebanyak 33 responden (54,1\%). Mayoritas jenis pekerjaan yang dimiliki oleh ibu responden adalah IRT, yaitu sebanyak 26 responden (42,6\%). Selain itu, frekuensi ibu yang menjadi responden memiliki status bekerja, yakni sebanyak 35 responden $(55,7 \%)$. Status gizi balita terbanyak adalah kategori normal, yaitu sebanyak 44 responden $(72,1 \%)$.

Tabel 2

Analisis Hubungan Status Pekerjaan Ibu Dengan Status Gizi Pada Balita

\begin{tabular}{ccccc}
\hline Status & \multicolumn{3}{c}{ Status Gizi } & \\
\cline { 2 - 4 } Pekerjaan & Kurus & Normal & Gemuk & P-value \\
\cline { 2 - 4 } Ibu & $\%$ & $\%$ & $\%$ & \\
\hline Bekerja & 8 & 31 & 18 & \\
Tidak & 2 & 41 & 0 & 0,001 \\
Bekerja & 2 & & \\
\hline Total & 10 & 72 & 18 & \\
\hline
\end{tabular}

Tabel 2 menunjukkan bahwa nilai pvalue $=0,001$ yang berarti nilai $p \leq 0,05$ maka Ho ditolak. Hal ini menunjukkan bahwa ada hubungan yang signifikan antara status pekerjaan ibu dengan status gizi balita di Wilayah Kerja UPT Puskesmas Kuta Utara.

\section{PEMBAHASAN}

Pengaruh ibu yang bekerja pada hubungan anak dan ibu, sebagian besar bergantung pada usia anak pada waktu ibu mulai bekerja. Jika ibu mulai bekerja sebelum anak telah terbiasa selalu bersamanya, yaitu sebelum suatu hubungan tertentu terbentuk, maka pengaruhnya akan minimal. Tetapi jika hubungan yang baik 
telah terbentuk, anak itu akan menderita akibat deprivasi maternal, kecuali jika seorang pengganti ibu yang memuaskan tersedia, yaitu seorang pengganti yang disukai anak dan yang mendidik anak dengan cara yang tidak akan menyebabkan kebingungan atau kemarahan di pihak anak (Hurlock, 2007). Menurut Hurlock (1999), pengaruh ibu yang bekerja terhadap hubungan ibu dan anak, sebagian besar tergantung pada usia anak pada waktu ibu mulai bekerja. Jika ia mulai bekerja sebelum anak terbiasa selalu bersamanya dan sebelum suatu hubungan terbentuk maka pengaruhnya akan mengakibatkan anak merasa kehilangan dan kurang perhatian.

Pekerjaan orang tua berkaitan dengan pendapatan keluarga, sehingga bisa dikatakan bahwa jenis pekerjaan juga bisa menentukan seseorang untuk memenuhi kebutuhan gizi keluarga. Ibu yang bekerja memiliki waktu yang lebih sedikit untuk mengasuh anaknya dibandingkan ibu yang tidak bekerja. Sehingga akan berpengaruh pada kualitas perawatan anak sehingga mempengaruhi status gizi anak. Ibu yang bekerja dengan jam kerja dari pagi sampai sore maka ibu tidak mempunyai banyak waktu untuk memperhatikan makanan dan kebutuhan nutrisi anaknya (Nafi'ah, 2015).

Berdasarkan analisis peneliti dari beberapa hasil penelitian mengenai status gizi balita, jika status gizi pada balita sangat dipengaruhi oleh asupan nutrisi yang didapatkan. Memperhatikan dan memberikan asupan nutrisi yang baik pada balita memerlukan waktu yang lebih untuk orang tua khususnya seorang ibu untuk bersama-sama dengan balita, apabila ibu menghabiskan waktu 6-7 jam untuk bekerja diluar rumah maka akan mengurangi waktu kebersamaan dengan anaknya. Kondisi ini dapat berpengaruh pada terpenuhinya asupan gizi pada anak tersebut. Jadi status pekerjaan ibu dapat berpengaruh pada asupan nutrisi balita yang berdampak pada status gizi anaknya. Keluarga akan saling memberikan dukungan baik secara fisik, emosi dan ekonomi. Seorang yang ibu memiliki pekerjaan, memiliki waktu yang sedikit daripada seorang ayah. Ibu yang sibuk bekerja biasanya memberi uang saku lebih kepada anak dengan harapan anak membeli sarapan di sekolah. Perilaku tersebut akan menjadi kebiasaan tidak sarapan pagi yang terus menerus akan mengakibatkan pemasukan gizi menjadi berkurang dan tidak seimbang sehingga pertumbuhan anak menjadi terganggu. Dengan demikian seorang anak yang biasa tidak sarapan pagi dalam jangka waktu lama akan berakibat buruk pada penampilan intelektualnya, prestasi di sekolah menurun dan penampilan sosial menjadi terganggu. Keluarga adalah lingkungan pertama dalam memberikan proses pertumbuhan anak dan berpengaruh terhadap keturunann dari keluarga yang kecendrungan memliki postur tubuh yang kurang ideal (Andriana, 2013).

Hasil penelitian yang dilakukan oleh Putri (2015) dengan judul "Faktor-Faktor Yang Berhubungan Dengan Status Gizi Anak Balita Di Wilayah Kerja Puskesmas Nanggalo Padang". Pada penelitian ini mendapatkan hasil bahwa balita yang mengalami status gizi kurang lebih banyak berasal dari keluarga yang ibunya bekerja dengan analisis bivariat terdapat hubungan yang bermakna antara pekerjaan ibu dengan status gizi balita. Hasil bivariat ini diperkuat dengan hasil analisis multivariat yang menunjukan bahwa pekerjaan ibu merupakan faktor yang paling berhubungan dengan status gizi balita. Ibu yang tidak bekerja dalam keluarga dapat mempengaruhi asupan gizi balita karena ibu berperan sebagai pengasuh dan pengatur konsumsi makanan anggota keluarga. Ibu yang bekerja tidak memiliki waktu yang cukup untuk mengasuh dan merawat anaknya sehingga anaknya dapat menderita gizi kurang.

\section{KESIMPULAN}

Implikasi

Berdasarkan pemaparan hasil penelitian diatas maka dapat disimpulkan terdapat hubungan yang signifikan dari status pekerjaan ibu dengan status gizi balita di Wilayah Kerja UPT Puskesmas Kuta Utara. Penelitian ini memiliki implikasi terhadap pelayanan dimana penelitian ini dapat menjadi acuan dan evidence based practice yang kemudian 
dapat digunakan sebagai bahan pertimbangan dalam meningkatkan pengetahuan orang tua sehingga berdampak pada tingkat kesadaran tentang gizi keluarga

\section{Keterbatasan}

Penelitian ini tidak mengendalikan secara implisit beberapa faktor yang berpontensi untuk diketahui pengaruhnya terhadap status gisi balita seperti jumlah anak, tingkat pengetahuan, tingkat pendidikan, penghasilan dan pola asuh pada balita.

\section{DAFTAR PUSTAKA}

Adriani, M., \& Wiryatmadi, B. (2012). Peranan Gizi dalam Siklus Kehidupan. Jakarta : Kencana.

Agus, U. (2012). Hubungan antara karakteristik ibu dengan status Gizi. Jurnal kesmasindo,

Andriana, D. (2013). Tumbuh Kembang Dan Terapi Bermainpada Anak. Jakarta: Salemba Medika

Dinas Kesehatan Kota Denpasa. (2016). Rencana Strategis Dinas Kesehatan Kota Denpasar tahun 2016-2021, Denpasar, Dikes Kota Denpasar

Hurlock, E. B. (1999). Perkembangan Perkembangan: Suatu Pendekatan sepanjang Rentang Kehidupan. Jakarta: Erlangga

Hurlock, E. B. (2007). Perkembangan Perkembangan: Suatu Pendekatan sepanjang Rentang Kehidupan. Jakarta: Erlangga

IFPRI. Global Nutrition Report (GNR). (2014). Actions and Accountability to Accelerate the World's Progress on Nutrition. Washington DC: International Food Policy Research Institute.

Nafi'ah, S. (2015). Gambaran Karakteristik Ibu Balita Yang Memiliki Gizi Kurang Di Desa Sambungwangan Kecamatan Randublatung Kabupaten Blora. Stikes Ngudi Waluyo.

Putri, D. S. K \& Wahyono, T. Y. M (2013). Faktor Langsung Dan Tidak Langsung Yang berhubungan dengan
Kejadian Wasting Pada Anak Umur 6-59 Bulan. Media Litbangkes

Wirjatmadi, R. B., Welasasih, B. D. (2012). "Beberapa faktor yang Berhubungan dengan Status Gizi Balita Stunting”. The Indonesian Journal of Public Health. 